\title{
Soil properties and root traits jointly shape fine-scale spatial patterns of bacterial community and metabolic functions within a Korean pine forest
}

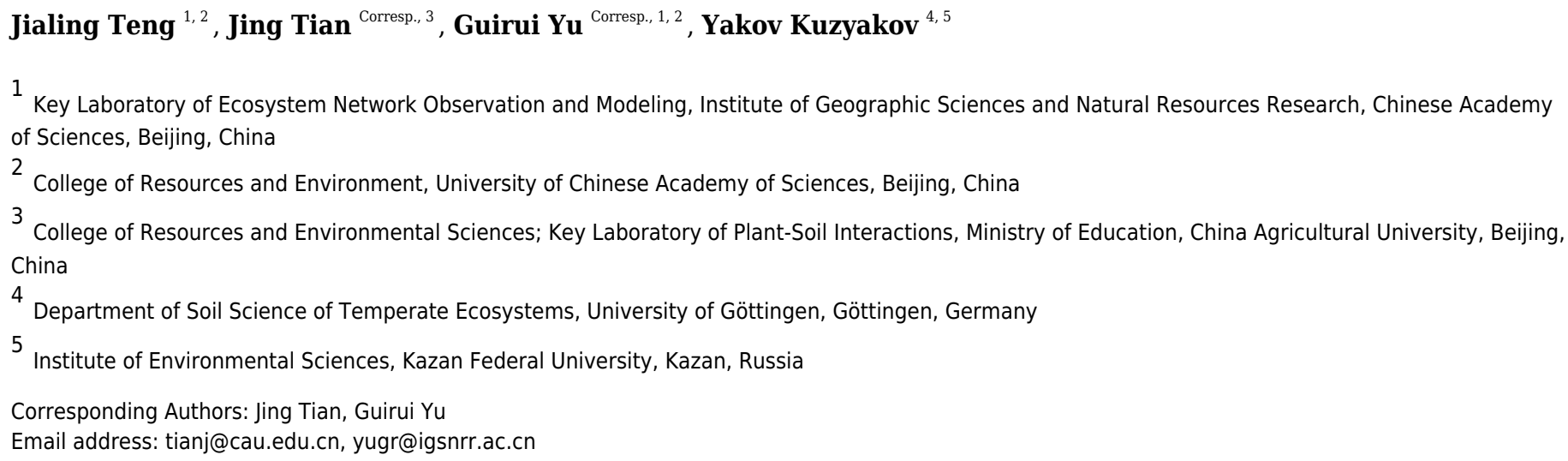

Spatial heterogeneity of soil bacterial community depends on scales. The fine-scale spatial heterogeneity of bacterial community composition and functions remains unknown. We analyzed the main driving factors of fine-scale spatial patterns of soil bacterial community composition and carbon metabolic functions across a $30 \mathrm{~m} \times 40 \mathrm{~m}$ plot within a Korean pine forest by combining Illumina 16S rRNA sequencing with Biolog Ecoplates based on 53 soil samples. Clear spatial patterns in bacterial community composition and metabolic functions were observed in the forest soil. The bacterial community composition and metabolic functions both showed distance-decay of similarity within a distance of meters. Structural equation model analysis revealed that environmental variables and geographic distance together explained $37.9 \%$ and $63.1 \%$ of community and metabolic functions, respectively. Among all environmental factors, soil organic carbon $(\mathrm{SOC})$ and root biomass emerged as the most important drivers of the bacterial community structure. In contrast, soil $\mathrm{pH}$ explained the largest variance in metabolic functions. Root biomass explained the second-largest variance in soil bacterial community composition, but root traits made no difference in metabolic functions variance. These results allow us to better understand the mechanisms controlling belowground diversity and plant-microbe interactions in forest ecosystems. 


\section{Soil properties and root traits jointly shape fine-scale spatial patterns}

\section{2 of bacterial community and metabolic functions within a Korean pine}

\section{3 forest}

4

Jialing Teng ${ }^{1,2}$, Jing Tian ${ }^{3}$, Guirui Yu ${ }^{1,2}$, Yakov Kuzyakov ${ }^{4,5}$

${ }^{1}$ Key Laboratory of Ecosystem Network Observation and Modeling, Institute of Geographic

8 Sciences and Natural Resources Research, Chinese Academy of Sciences (CAS), Beijing,

9 China

$10{ }^{2}$ College of Resources and Environment, University of Chinese Academy of Sciences, Beijing, 11 China

$12{ }^{3}$ College of Resources and Environmental Sciences; Key Laboratory of Plant-Soil Interactions, 13 Ministry of Education, China Agricultural University, Beijing, China

${ }^{4}$ Department of Soil Science of Temperate Ecosystems, University of Göttingen, Göttingen, Germany

${ }^{5}$ Institute of Environmental Sciences, Kazan Federal University, Kazan, Russia

Corresponding Author:

19 Jing Tian

Email address: tianj@cau.edu.cn

22 Guirui Yu

23 Address: 11A, Datun Road, Chaoyang District, Beijing, 100101, China

24 Email address: yugr@igsnrr.ac.cn

25

26

\section{Abstract}

Spatial heterogeneity of soil bacterial community depends on scales. The fine-scale spatial the main driving factors of fine-scale spatial patterns of soil bacterial community composition and carbon metabolic functions across a $30 \mathrm{~m} \times 40 \mathrm{~m}$ plot within a Korean pine forest by combining Illumina 16S rRNA sequencing with Biolog Ecoplates based on 53 soil samples. Clear spatial patterns in bacterial community composition and metabolic functions were observed in the forest soil. The bacterial community composition and metabolic functions both showed distance-decay of similarity within a distance of meters. Structural equation model analysis revealed that environmental variables and geographic distance together explained 37.9\% and $63.1 \%$ of community and metabolic functions, respectively. Among all environmental 
38

39

40

41

42

43

44

45

46

47

48

49

50

51

52

53

54

55

56

57

58

59

60

61

62

63

64

65

66

67

68

69

70

71

72

73

74

75

76

77

bacterial community structure. In contrast, soil $\mathrm{pH}$ explained the largest variance in metabolic functions. Root biomass explained the second-largest variance in soil bacterial community composition, but root traits made no difference in metabolic functions variance. These results allow us to better understand the mechanisms controlling belowground diversity and plantmicrobe interactions in forest ecosystems.

\section{Introduction}

Soil bacteria drive important biogeochemical processes and play critical roles in regulating the functions and stability of ecosystems (Fuhrman 2009; Lladó et al. 2017; Sugden 2018). The geographic distribution of soil bacteria has been recently examined across a broad range of spatial scales (Griffiths et al. 2011; Martiny et al. 2011; Ranjard et al. 2013; Sugden 2018). Most of these studies compared samples collected more than $1 \mathrm{~km}$ apart, and studies on fine-scale $(<1$ $\mathrm{km}$ ) are still very rare (Finkel et al. 2012; Lear et al. 2014). The fine-scale spatial patterns of soil bacteria are important for understanding bacterial community dynamics and providing appropriate scales to monitor the communities of forest soil. However, there are still important gaps in identifying the distances of patterns in community composition and diversity. In particular, the minimum spatial scales have significant biogeographic patterns (Finkel et al. 2012; Lear et al. 2014; Martiny et al. 2006).

Many environmental factors can directly or indirectly influence the spatial structure of soil bacterial communities. The soil $\mathrm{pH}$ has the clearest effects on the variance in the abundance of soil bacterial taxa (Fierer 2017; Liu et al. 2014; Shen et al. 2013; Tripathi et al. 2018). The other most important factors influencing the structure of soil bacterial communities are quantity and quality of organic carbon (Delgado-Baquerizo \& Eldridge 2019; Tian et al. 2012; Tian et al. 2018), climate factors (Bahram et al. 2018; Delgado-Baquerizo et al. 2017; Delgado-Baquerizo \& Eldridge 2019; Ladau et al. 2018) and redox status (DeAngelis et al. 2010). Besides edaphic factors, plants are key drivers of soil bacterial community structure and functions (Bardgett et al. 2005; de Vries et al. 2012; Delgado-Baquerizo et al. 2018a; Prober et al. 2015). Plants have significant influences on carbon resources and modify the habitats of soil bacteria (Kuzyakov et al. 2000; Latz et al. 2015). Plant diversity is a strong predictor of soil microbial diversity (Cantarel et al. 2016; Lamb et al. 2011; Prober et al. 2015; Wang et al. 2016), and influence microbial communities via specific functional traits. Leaf traits (Laughlin 2011) have important roles in regulating soil microbial communities (de Vries et al. 2012; Delgado-Baquerizo et al. 2018b). However, much less is known about the role of roots in regulating the soil bacterial communities (de Vries et al. 2012; Delgado-Baquerizo et al. 2018b; Pervaiz et al. 2020). Forests are spatially heterogeneous ecosystems (Stursova et al. 2016) at scales of meters, within which soil, roots, and microbes form extremely complex dependencies and relationships through substance, energy, and information exchange (Feeney et al. 2006). The roots are one of the two dominant sources of $\mathrm{C}$ input variability in temperate forest soils (Baldrian et al. 2010; Clemmensen et al. 2013). Root-derived $C$ forms easily available energy and supports a high abundance, activity, and diversity of microorganisms (Pausch \& Kuzyakov 2011). Active fine 
78

79

80

81

82

83

84

85

86

87

88

89

90

91

92

93

94

95

96

97

98

99

100

101

102

103

104

105

106

107

108

109

110

111

112

113

114

115

116

117

roots with fast turnover and their symbiotic microorganisms distribute throughout the soil and undertake essential functions for plants such as nutrient and water acquisition (Finzi et al. 2015; Phillips \& Fahey 2006; Waisel et al. 2002; Zhao et al. 2010) and influence various ecological processes (Bardgett \& Wh 2014; Cadotte et al. 2009; Clemmensen et al. 2013; Freschet \& Cornelissen 2013). Active fine roots or tips can release more exudates into soil (Dennis et al. 2010; Jones et al. 2009), which have an important influence on soil microbial communities (Denef et al. 2009; Tian et al. 2012).

Functional trait approaches have been demonstrated to be a beneficial tool for analyzing plantmicrobial interactions (Cantarel et al. 2016; de Vries et al. 2012; Grigulis et al. 2013). For example, root diameter represents the ability of root to penetrate dense soil (Materechera et al. 1991), colonizing by mycorrhiza (Comas et al. 2014), whereas specific root length (SRL) reflects the efficiency of exploration or exploitation at the cost of root longevity (Eissenstat et al. 2000; McCormack et al. 2012). Despite growing evidences that the effects of root traits on ecosystem processes largely via interactions with free-living microorganisms (Bardgett et al. 2014; Freschet et al. 2017), our knowledge of the specific traits that affect soil bacterial community composition and metabolic functions is limited.

In this context, we hypothesize that 1) bacterial community composition and carbon metabolic functions show distance-decay of similarity at a scale of few meters or tens of meters; and 2) environmental conditions, including soil properties and root traits explain more variance in bacterial community composition and metabolic functions than geographical distance because roots are the main direct drivers and the distance exerts indirect effects through the trees and their roots. To test these hypotheses, we investigated the significance of geographic distance, soil properties, and root traits in shaping the bacterial community composition and functions within a broad-leaved Korean pine forest.

\section{Materials \& Methods}

\section{Study site and sampling}

The study was designed in an original Korean pine forest within the Forest Ecosystem Open Research Station of the Changbai Mountains in northeast China $\left(128^{\circ} 28^{\prime} \mathrm{E}, 42^{\circ} 24^{\prime} \mathrm{N}\right)$ at an altitude of 700-800 $\mathrm{m}$ above sea level. This area is a typical warm temperate zone continental monsoon climate, with a mean air temperature of $2.0^{\circ} \mathrm{C}$ and mean annual precipitation of approximately $700 \mathrm{~mm}$. This region is dominated by brown forest soil, which originated from volcanic ash, and is classified as a Haplic Andosol (Zhang et al. 2006). The vegetation community of the sampling plot is a multi-story forest with different ages, averaging over 200 years. The upper strata mainly include Pinus koraiensis, Tiliaamurensis, Acer mono, Acer barbinerve, Fraxinus mandshurica, Acer ktegmentosum, Ulmus japonica, and Quercus mongolica. The dominant shrubs and herbs include Corylusmandshurica, Deutzia amurensis, Brachybotrysparidiformis, and Phrymaleptostachya.

A total of 53 soil samples were collected (Fig. S1) from 0 to $10 \mathrm{~cm}$ depth from a $30 \mathrm{~m} \times 40 \mathrm{~m}$ plot following the Latin hypercube design in August 2013, as described in Tian et al. (2015). 
118 Latin hypercube sampling is a stratified-random procedure that provides an efficient way to

119

120

121

122

123

124

125

126

127

128

129

130

131

132

133

134

135

136

137

138

139

140

141

142

143

144

145

146

147

148

149

150

151

152

153

154

155

156

157

ensure full coverage of the range of each variable by maximally stratifying the marginal distribution (McKay et al. 1979). This design produces a statistically robust sampling scheme to capture the spatial variability of soils in the study area and is the most effective way to replicate the distribution of the variables (Helton \& Davis 2003; Mulder et al. 2013). The sampling points had a minimum distance of $0.49 \mathrm{~m}$ and a maximum of $44 \mathrm{~m}$. The samples were stored in airtight polypropylene bags, placed in a cooler box at about $4{ }^{\circ} \mathrm{C}$ during sampling and transported to the laboratory. The visible roots, rock fragments, and residues were carefully removed by hand, and then the roots were carefully washed with tap water to remove the adhering soil. Then samples were frozen at $-20{ }^{\circ} \mathrm{C}$ until the measurements. The soil samples were divided into several subsamples. The subsamples for microbial functional diversity and dissolved organic matter concentration analysis were stored at $4{ }^{\circ} \mathrm{C}$ for no more than one week. The subsamples for microbial communities were stored at $-80{ }^{\circ} \mathrm{C}$. The subsamples for organic matter analyses were air dried.

\section{Soil chemical analyses}

The air-dried samples were passed through a $2 \mathrm{~mm}$ sieve, then ball-milled and analyzed for soil organic carbon (SOC) and total nitrogen (TN) contents by dry combustion with a Vario Max CN elemental analyzer (Elementar, Langenselbold, Germany). The soil dissolved organic carbon (DOC) and total dissolved nitrogen (DON) concentrations were determined using a Multi 3100 $\mathrm{N} / \mathrm{C}$ TOC analyzer (Analytik Jena, Jena, Germany). The soil $\mathrm{NH}_{4}{ }^{+}$and $\mathrm{NO}_{3}{ }^{-}$concentrations were measured using an autoanalyzer (TRAACS-2000, BRAN+ LUEBBE, Norderstedt, Germany). The soil DON was calculated as the difference between the total dissolved $\mathrm{N}$ and the combined $\mathrm{NH}_{4}{ }^{+}$and $\mathrm{NO}_{3}{ }^{-}$. The particulate organic carbon and nitrogen (POC and PON, respectively) were determined by the method reported by Cambardella and Elliott (1992). Soil pH was determined using a pH meter after shaking the soil in deionized water (soil-to-water ratio of 1:2.5) suspensions for $30 \mathrm{~min}$.

\section{Analyses of soil bacterial community composition and carbon metabolic functions}

The soil microbial functional diversity was characterized using Biolog Eco-plates (Hayward, CA, USA) (Garland \& Mills 1991). Thirty-one C substrates associated with plant root exudates were used in the Eco-plates. Dividing them into six groups: seven carbohydrates $(\beta-M e t h y l-D-$ glucoside, D-Xylose, i-Erythritol, d-Mannitol, N-Acetyl- ${ }^{-}$-galactosamine, D-Cellobiose and $\alpha$-DLactose), six amino acids (L-Arginine, L-Asparagine, L-Phenylalanine, L-Serine, L-Threonine, and Glycyl- L-glutamic acid), nine carboxylic acids (D-Galactonic acid $\gamma$-lactone, DGalacturonic acid, 2-Hydroxy benzoic acid, 4-Hydroxy benzoic acid, $\gamma$-Hydroxy butyric acid, Itaconic acid, $\alpha$-Keto butyric acid, D-Glucosaminic acid and D-Malic acid), two amines (Phenylethylamine and Putrescine), four polymers (Tween 40, Tween 80, $\alpha$-Cyclodextrin and Glycogen), and three miscellaneous (Pyruvic acid methyl ester, D,L- $\alpha$-Glycerol phosphate and Glucose-L-phosphate). Briefly, $10 \mathrm{~g}$ of fresh soil was added to $90 \mathrm{~mL}$ of sterilized $\mathrm{NaCl}(0.85 \%)$ solution and shaken at $200 \mathrm{rpm} \mathrm{min}^{-1}$ for $30 \mathrm{~min}$. Ten-fold serial dilutions were prepared, and each well of the Biolog Eco-plates was inoculated with $150 \mu \mathrm{L}$ of the $10^{-2}$ suspension. The plates

PeerJ reviewing PDF | (2020:09:52658:2:0:NEW 12 Jan 2021) 
158

159

160

161

162

163

164

165

166

167

168

169

170

171

172

173

174

175

176

177

178

179

180

181

182

183

184

185

186

187

188

189

190

191

192

193

194

195

196

197

were incubated at $30^{\circ} \mathrm{C}$ for 10 days, and the color development was read as absorbance every 24 $\mathrm{h}$ with an automated plate reader (VMAX, Molecular Devices, Crawley, UK) at a wavelength of $590 \mathrm{~nm}$. The $72 \mathrm{~h}$ absorbance values were used to calculate the average well color development (AWCD) and indicated the microbial metabolic activity.

Soil DNA was extracted from each sample using the PowerSoil kit (MoBioLaboratories, Carlsbad, CA, USA) according to the manufacturer's instructions. The quality of the purified DNA was assessed based on the $260 / 280 \mathrm{~nm}$ and $260 / 230 \mathrm{~nm}$ absorbance ratios obtained, using a NanoDrop ND-1000 spectrophotometer (NanoDrop Technologies Inc., Wilmington, DE, USA). The DNA was stored at $-80^{\circ} \mathrm{C}$ until use.

An aliquot of the extracted DNA from each sample was used as a template for amplification. The V3-V4 hypervariable regions of bacterial 16S rRNA genes were amplified using the primers 338F 5'-barcode-ACTCCTACGGGAGGCAGCAG-3' and 806R 5'-

GGACTACHVGGGTWTCTAAT-3'. PCR reactions were performed in triplicate with a $20 \mu \mathrm{L}$ mixture containing $4 \mu \mathrm{L}$ of $5 \times$ FastPfu Buffer, $2 \mu \mathrm{L}$ of $2.5 \mathrm{mM}$ dNTPs, $0.8 \mu \mathrm{L}$ of each primer ( 5 $\mu \mathrm{M}), 0.4 \mu \mathrm{L}$ of FastPfuPolymerase, and $10 \mathrm{ng}$ of template DNA. The following thermal program was used for amplification: $95^{\circ} \mathrm{C}$ for $3 \mathrm{~min}$, followed by 27 cycles at $95^{\circ} \mathrm{C}$ for $30 \mathrm{~s}, 55^{\circ} \mathrm{C}$ for 30 $\mathrm{s}$, and $72^{\circ} \mathrm{C}$ for $45 \mathrm{~s}$ and a final extension at $72^{\circ} \mathrm{C}$ for $10 \mathrm{~min}$. PCR amplicons were extracted from 2\% agarose gels and purified using an AxyPrep DNA Gel Extraction Kit (Axygen Biosciences, Union City, CA, USA) according to the manufacturer's instructions and quantified using QuantiFluor ${ }^{\mathrm{TM}}$-ST (Promega, USA). The purified amplicons from all samples were pooled at equimolar concentrations. Sequencing was conducted on an Illumina MiSeq platform at Majorbio Bio-Pharm Technology Co., Ltd. (Shanghai, China).

Raw sequences $>200$ bp with an average quality score $>20$ and without ambiguous base calls were quality processed, using the Quantitative Insights into Microbial Ecology (QIIME) pipeline (version 1.17). Operational taxonomic units (OTUs) were clustered with a $97 \%$ similarity cutoff using UPARSE (version $7.1 \mathrm{http} / /$ drive5.com/uparse/). The taxonomic assignment was performed using the Ribosomal Database Project (RDP) classifier (http://rdp.cme.msu.edu/). To correct for sampling effort (number of analyzed sequences per sample), we used a randomly selected subset of 19,460 sequences per sample for subsequent analysis.

\section{Root traits}

The fine root samples (diameter $<1 \mathrm{~mm}$, including roots for absorption and transportation) were selected for scanning on a desktop scanner, and images were processed with WinRHIZO (Regent Instruments Inc., Quebec City, QC, Canada) to determine the average root diameter and total root length. These roots were then oven-dried to a constant weight. Specific root length (SRL) was calculated as the ratio of total root length to root dry weight, and root tissue density (RTD) was calculated as the ratio of root dry weight to root volume.

\section{Data analysis}

For the analyses of bacterial community composition and function similarity, we calculated pairwise environmental distances (Euclidean distance) and a pairwise community Bray-Curtis dissimilarity matrix for the whole set of bacterial OTUs and Biolog data within the vegan 
198

199

200

201

202

203

204

205

206

207

208

209

210

211

212

213

214

215

216

217

218

219

220

221

222

223

224

225

226

227

228

229

230

231

232

233

234

235

236

package using R (R Core Team, 2016). Mantel tests (10,000 permutations) were used to explore the significance of the influence of geographical distance on Bray-Curtis dissimilarities.

We used structural equation modeling (SEM) to evaluate the direct and indirect relationships between geographical distance, soil properties, root traits, and bacterial community composition and functions. First, we established an a priori model based on the known effects and relationships among the drivers of community composition and function. Then we parameterized the model using our dataset and tested its overall goodness of fit. We used the $\chi^{2}$-test and root mean square error of approximation (RMSEA). Furthermore, we calculated the standardized total effects of distance, soil properties and root traits on soil bacterial community composition and function. All the SEM analyses were conducted using AMOS 20.0 (AMOS IBM, USA) (Grace \& Keeley 2006).

\section{Results}

\section{Spatial variability of soil properties, root traits and bacterial community}

We identified a total of 1,233,787 high-quality bacterial sequences grouped into 10,739 OTUs. The average number of bacterial sequences per sample was 23,279, which were classified as 2,311 to 3,402 OTUs (with an average of 2,901 \pm 32 OTUs, Table S1). The bacterial alpha diversity (Shannon index) varied from 5.73-6.84, with an average of 6.28. The dominant phyla of bacterial communities across all soil samples were Proteobacteria, Acidobacteria, Actinobacteria, Chloroflexi, Verrucomicrobia, Bacteroidetes, Nitrospirae and Gemmatimonadetes (relative abundance $>1 \%$, Fig. 1), which accounted for more than $95 \%$ of the bacterial sequences. Alphaproteobacteria and Acidobacteria were most abundant at the class level, and the dominant classes (relative abundance $>2 \%$ ) also included Spartobacteria, Thermoleophilia, Actinobacteria, Deltaproteobacteria, Betaproteobacteria, and the other five classes, accounting for about $85 \%$ of the bacterial sequences (Fig. 1).

Metabolic activity (indicated as AWCD) and diversity varied from 0.51-1.57, and 2.19-3.35 with an average of 1.00 and 2.59, respectively (Table S1). Despite the fine scale of the research site (only $30 \times 40 \mathrm{~m}^{2}$ ), the root traits, soil parameters, bacterial community composition, and metabolic functions presented a high degree of spatial variance (Table S1). While the CVs of pH and Shannon-Wiener diversity index of bacterial community composition were relatively small, with CVs $<20 \%$, the other parameters had a high level of variance $(>20 \%)$.

Microbial metabolic activities were related to the abundance of multiple bacterial classes in the phyla of Verrucomicrobia, Proteobacteria, Planctomysetes, Cyanobacteria, Chloroflexi, Bacteroidetes, and Actinobacteria (Fig. 2). The stepwise regression analysis showed that the six metabolic groups were all related to soil $\mathrm{pH}(28.9-57.8 \%)$, DOC (17.1-32.1\%) and various bacterial classes (16.8-53.5\%) (Table S2, S3).

\section{Distance-decay patterns of bacterial community composition and metabolic functions}


237 Dissimilarities (Bray Curtis index) in the bacterial community composition and metabolic

238

239

240

241

242

243

244

245

246

247

248

249

250

251

252

253

254

255

256

257

258

259

260

261

262

263

264

265

266

267

268

269

270

271

272

273

274

275

276

functions were positively correlated with geographic distance (Mantel $r=0.194, p<0.05$; Mantel $r=0.119, p<0.05$ ) (Fig. 3). At the phylum level, besides Proteobacteria and Actinobacteria, the other dominant bacterial groups (Acidobacteria, Chloroflexi, Verrucomicrobia, Bacteroidetes, Nitrospirae, and Gemmatimonadetes) all showed distancedecay patterns (Fig. 4). Microbial metabolic activities towards carbohydrates, carboxylic acids, polymers, and amines presented distance-decay patterns (Fig. 5).

The multivariate Mantel correlogram showed that for bacterial community composition, the first three distance classes had a positive autocorrelation ( $p<0.05$; i.e., up to $16.1 \mathrm{~m})$, while the next two classes have a negative autocorrelation ( $p<0.05$; i.e., up to $26.5 \mathrm{~m}$ ) (Fig. 6). No significant autocorrelations were found for the further distance class. However, the correlogram showed a sudden significant decrease in autocorrelation $(p<0.05)$ only at the smallest distance class (i.e., up to $5.7 \mathrm{~m}$ ) (Fig. 6). This pattern indicated an abrupt change in metabolic functions with increasing distance.

\section{Drivers of bacterial community composition and carbon metabolic functions}

Soil properties and root traits (root biomass and SRL) together shaped the bacterial community and affected metabolic activity (Figs. 7 and 8$)$. The bacterial diversity $\left(\mathrm{H}^{\prime}\right)$ was related to $\mathrm{pH}(p$ $<0.01)$ and $\mathrm{C} / \mathrm{N}(p<0.05)$, while the functional diversity was only related to DOC concentration $(p<0.01)$ (Fig. 7). Bacterial community composition and functional groups were related to various soil and root properties (Fig. 7). The relative abundances of bacterial groups were mainly related to $\mathrm{pH}, \mathrm{SOC}, \mathrm{TN}, \mathrm{DOC}$, and $\mathrm{SRL}$, while the metabolic groups were related to $\mathrm{pH}, \mathrm{SOC}$, TN, C/N, DOC, POC and PON (Fig. 7).

The SEMs explained $37.9 \%$ and $63.1 \%$ of the variance found in bacterial community composition and metabolic functions (Fig. 8), respectively. The distance only affected the bacterial community directly via its influence on soil properties (Fig. 8). Root biomass had a positive effect on bacterial community composition. SOC, $\mathrm{C} / \mathrm{N}, \mathrm{pH}$, and root biomass collectively contributed to the variance of bacterial community composition, among which SOC and root biomass contributed the most (Fig. 8a). In contrast, $\mathrm{pH}$ was the dominant driver in determining the variance of metabolic functions (Fig. 8b). Specifically, the root traits made a difference in bacterial community composition but were irrelevant to functional differences.

\section{Discussion}

Soil bacteria are the most abundant and diverse group of organisms on Earth, driving many ecosystem processes (Bardgett \& Wh 2014; Delgado-Baquerizo et al. 2018b; Sugden 2018). Understanding bacterial biogeographical patterns and drivers is crucial for resolving the complex and coordinated microbial mechanisms of maintaining soil nutrient cycling. Distance-decay relationships exist in the distribution of bacterial communities (Fierer \& Jackson 2006; Ranjard et al. 2013; Sugden 2018). Nevertheless, few investigations have yet been conducted at fine spatial scales.

PeerJ reviewing PDF | (2020:09:52658:2:0:NEW 12 Jan 2021) 
277 A correlogram that declines from significant positive correlations at short distances to significant 278 negative correlations at large distances is consistent with a patchy spatial distribution (Legendre 279 \& Fortin 1989). We confirmed the distance-decay patterns of bacterial communities and 280 functions at smaller spatial scales than most previous studies of forest soil. These findings 281 improved our understanding of bacterial community variability at a fine scale and provided 282 appropriate scales to monitor the microbial communities of forest soil. Furthermore, these results 283 showed that the bacterial community composition and metabolic functions presented an obvious 284 asymmetric variance (Fig. 6), which could be due to the dispersal in the bacterial community was 285 higher than that of microbes responsible for metabolic functions (Lear et al. 2014). Certain 286 microbial community functions are in fact driven more by low levels of the bacterial groups with 287 288 289 290 291

292

293 relatively limited dispersal ability (Lear et al. 2014; Severin et al. 2013), while other abundant groups that are less responsible for community functions had more ability to disperse and colonize new habitats (Lear et al. 2014).

The spatial heterogeneity mainly arose from the soil properties and root traits, rather than distance or dispersal limitations at the fine scale. The spatial patterns in the soil bacterial community at the fine scale were mainly due to soil properties and root traits (Fig. 8). The parameters we measured explained $37.9 \%$ and $63.1 \%$ of the variance of soil bacterial community composition and metabolic functions, respectively. Our findings are in line with previous research demonstrating the dominant effects of $\mathrm{pH}$ in shaping the soil bacterial community of Changbai Mountain (Shen et al. 2013). The importance of $\mathrm{pH}$ in shaping soil bacterial communities has been studied at various scales (Fierer \& Jackson 2006; Liu et al. 2014; Tripathi et al. 2018) and all results indicated the pivotal role of $\mathrm{pH}$ in controlling bacterial communities (Delgado-Baquerizo et al. 2018b; Rousk et al. 2010; Shen et al. 2013). Some explanations may explain the effects of soil $\mathrm{pH}$ on metabolic functions. First, soil $\mathrm{pH}$ impacts the substrates and microenvironment for metabolic reactions (Berg \& Mcclaugherty 2013; Jones et al. 2019), which change the microbial metabolic activity directly. Second, soil $\mathrm{pH}$ changes the abundance and activity of microbes participating in the metabolic reaction (Berg \& Mcclaugherty 2013; Jones et al. 2019). The effects of soil $\mathrm{pH}$ on metabolic functions are the result of the combined action of various factors. In addition to $\mathrm{pH}$, the effects of other soil properties, such as soil organic matter content are important (Delgado-Baquerizo et al. 2018b; Lladó et al. 2017; Tian et al. 2015). The plant communities influence the below-ground communities by litterfall and root rhizodeposition. Fine roots and their symbiotic microorganisms play important roles in soil nutrient availability and soil organic matter decomposition (Finzi et al. 2015; Han et al. 2020; López-Angulo et al. 2020; Saleem et al. 2020). Root traits reflect the quantity and quality of root litter and exudate transferred into the soil organic matter pool (Henneron et al. 2020; Klimešová et al. 2018; See et al. 2019) and decomposed by soil microbes. However, we only found that the root biomass contributed to variance in bacterial community composition but were uncorrelated with carbon metabolic functions, and there was no significant relationship between root traits and SOC. This may be due to the dual effects of roots on SOC (Dijkstra et al. 2020), in which roots increase SOC in forms of root litter and exudate, but also carbon input from roots promotes SOC 
317 decomposition because of the priming effect. Thus, we did not find a significant relationship 318 between root biomass and SOC, but both affected soil the bacterial community directly. Larger 319 root biomass per unit area implied more rhizodeposition that promoted certain groups of 320 bacterial growth, such as the Actinobacteria phylum, which resulted in variance of bacterial 321 community composition. On the other hand, metabolic functions were driven more by low levels 322 of the bacterial groups, and those root-affected groups were less responsible for metabolic

323 324

325

326

327

328

329

330

331

332

333

334

335

336

337

338

339

340

341

342

343

344

345

346

347

348

349

350

351

352

353

354

355

356

357

358 functions, leading to different effects of root traits on community composition and functions.

\section{Conclusions}

The bacterial metabolic functions and community composition varied significantly at a scale of a few meters and tens of meters, respectively, due to the heterogeneity of forest soil. Soil nutrient contents ( $\mathrm{SOC}$ and $\mathrm{C} / \mathrm{N}), \mathrm{pH}$, and root biomass together accounted for $37.9 \%$ of the variance in bacterial community composition, while only $\mathrm{pH}$ and nutrients contributed to $63.1 \%$ of the variance in metabolic functions. Root traits only affected community composition, but made no difference in the variance of metabolic functions. Geographical distance had only indirect effects via soil properties. This finding revealed that the synthesis of soil-roots-microbes should be think comprehensively in future studies.

\section{Acknowledgments}

We thank the National Natural Science Foundation of China (Grant No. 31770560), and the Major Program of the National Natural Science Foundation of China (Grant No. 2017YFA0604803) for generous financial support.

\section{References}

Bahram M, Hildebrand F, Forslund SK, Anderson JL, Soudzilovskaia NA, Bodegom PM, Bengtsson-Palme J, Anslan S, Coelho LP, Harend H, Huerta-Cepas J, Medema MH, Maltz MR, Mundra S, Olsson PA, Pent M, Põlme S, Sunagawa S, Ryberg M, Tedersoo L, and Bork P. 2018. Structure and function of the global topsoil microbiome. Nature 560:233-237. 10.1038/s41586-018-0386-6

Baldrian P, Merhautová V, Cajthaml T, Petránková M, and Šnajdr J. 2010. Small-scale distribution of extracellular enzymes, fungal, and bacterial biomass in Quercus petraea forest topsoil. Biology Fertility of Soils 46:717-726.

Bardgett RD, Bowman WD, Kaufmann R, and Schmidt SK. 2005. A temporal approach to linking aboveground and belowground ecology. Trends in Ecology \& Evolution 20:634641.

Bardgett RD, Mommer L, and De Vries FT. 2014. Going underground: root traits as drivers of ecosystem processes. Trends in Ecology and Evolution 29:692-699.

Bardgett RD, and Wh VDP. 2014. Belowground biodiversity and ecosystem functioning. Nature 515:505-511.

Berg B, and Mcclaugherty C. 2013. Plant Litter. Decomposition, Humus Formation, Carbon Sequestration. 
359

360

361

362

363

364

365

366

367

368

369

370

371

372

373

374

375

376

377

378

379

380

381

382

383

384

385

386

387

388

389

390

391

392

393

394

395

396

397

398

399

400

401

402

403

404

405

406

407

408

Cadotte MW, Cavender-Bares J, Tilman D, and Oakley TH. 2009. Using phylogenetic, functional and trait diversity to understand patterns of plant community productivity. Plos One 4:e5695.

Cambardella CA, and Elliott ET. 1992. Particulate Soil Organic-Matter Changes across a Grassland Cultivation Sequence. Soil Science Society of America Journal 56:777-783. DOI 10.2136/sssaj1992.03615995005600030017x

Cantarel AAM, Pommier T, Desclos-Theveniau M, Diquélou S, Dumont M, Grassein F, Kastl EM, Grigulis K, Laîné P, and Lavorel S. 2016. Using plant traits to explain plant-microbe relationships involved in nitrogen acquisition. Ecology 96:788-799.

Clemmensen KE, Bahr A, Ovaskainen O, Dahlberg A, Ekblad A, Wallander H, Stenlid J, Finlay RD, Wardle DA, and Lindahl BD. 2013. Roots and associated fungi drive long-term carbon sequestration in boreal forest. Science 339:1615-1618.

Comas LH, Callahan HS, and Midford PE. 2014. Patterns in root traits of woody species hosting arbuscular and ectomycorrhizas: implications for the evolution of belowground strategies. Ecology and Evolution 4:2979-2990. 10.1002/ece3.1147

de Vries FT, Manning P, Tallowin JR, Mortimer SR, Pilgrim ES, Harrison KA, Hobbs PJ, Quirk H, Shipley B, and Cornelissen JH. 2012. Abiotic drivers and plant traits explain landscape-scale patterns in soil microbial communities. Ecology Letters 15:1230-1239.

DeAngelis KM, Silver WL, Thompson AW, and Firestone MK. 2010. Microbial communities acclimate to recurring changes in soil redox potential status. Environmental Microbiology 12:3137-3149.

Delgado-Baquerizo M, Bissett A, Eldridge DJ, Maestre FT, He J-Z, Wang J-T, Hamonts K, Liu Y-R, Singh BK, and Fierer N. 2017. Palaeoclimate explains a unique proportion of the global variation in soil bacterial communities. Nature Ecology \& Evolution 1:1339-1347. 10.1038/s41559-017-0259-7

Delgado-Baquerizo M, and Eldridge DJ. 2019. Cross-Biome Drivers of Soil Bacterial Alpha Diversity on a Worldwide Scale. Ecosystems 22:1220-1231. 10.1007/s10021-018-03332

Delgado-Baquerizo M, Fry EL, Eldridge DJ, de Vries FT, Manning P, Hamonts K, Kattge J, Boenisch G, Singh BK, and Bardgett RD. 2018a. Plant attributes explain the distribution of soil microbial communities in two contrasting regions of the globe. New Phytologist 219:574-587. https://doi.org/10.1111/nph.15161

Delgado-Baquerizo M, Oliverio AM, Brewer TE, Benavent-González A, Eldridge DJ, Bardgett RD, Maestre FT, Singh BK, and Fierer N. 2018b. A global atlas of the dominant bacteria found in soil. Science 359:320.

Denef K, Roobroeck D, Wadu MCWM, Lootens P, and Boeckx P. 2009. Microbial community composition and rhizodeposit-carbon assimilation in differently managed temperate grassland soils. Soil Biology \& Biochemistry 41:144-153. 10.1016/j.soilbio.2008.10.008

Dennis PG, Miller AJ, and Hirsch PR. 2010. Are root exudates more important than other sources of rhizodeposits in structuring rhizosphere bacterial communities? Fems Microbiology Ecology 72:313-327. 10.1111/j.1574-6941.2010.00860.x

Dijkstra FA, Zhu B, and Cheng W. 2020. Root effects on soil organic carbon: a double-edged sword. New Phytologist n/a. https://doi.org/10.1111/nph.17082

Eissenstat DM, Wells CE, Yanai RD, and Whitbeck JL. 2000. Building roots in a changing environment: implications for root longevity. New Phytologist 147:33-42.

Feeney DS, Crawford JW, Daniell T, Hallett PD, Nunan N, Ritz K, Rivers M, and Young IM. 2006. Three-dimensional Microorganization of the Soil-Root-Microbe System. Microbial Ecology 52:151-158.

Fierer N. 2017. Embracing the unknown: disentangling the complexities of the soil microbiome. Nature Reviews Microbiology 15:579-590. 10.1038/nrmicro.2017.87

PeerJ reviewing PDF | (2020:09:52658:2:0:NEW 12 Jan 2021) 
409

410

411

412

413

414

415

416

417

418

419

420

421

422

423

424

425

426

427

428

429

430

431

432

433

434

435

436

437

438

439

440

441

442

443

444

445

446

447

448

449

450

451

452

453

454

455

456

457

Fierer N, and Jackson RB. 2006. The diversity and biogeography of soil bacterial communities. Proceedings of the National Academy of Sciences of the United States of America 103:626-631. 10.1073/pnas.0507535103

Finkel OM, Burch AY, Elad T, Huse SM, Lindow SE, Post AF, and Belkin S. 2012. DistanceDecay Relationships Partially Determine Diversity Patterns of Phyllosphere Bacteria on Tamrix Trees across the Sonoran Desert. Applied and Environmental Microbiology 78:6187-6193. 10.1128/Aem.00888-12

Finzi AC, Abramoff RZ, Spiller KS, Brzostek ER, Darby BA, Kramer MA, and Phillips RP. 2015. Rhizosphere processes are quantitatively important components of terrestrial carbon and nutrient cycles. Global Change Biology 21:2082-2094.

Freschet GT, and Cornelissen JHC. 2013. Linking litter decomposition of above- and belowground organs to plant-soil feedbacks worldwide. Journal of Ecology 101:943-952.

Freschet GT, Valverde-Barrantes OJ, Tucker CM, Craine JM, McCormack ML, Violle C, Fort F, Blackwood CB, Urban-Mead KR, Iversen CM, Bonis A, Comas LH, Cornelissen JHC, Dong M, Guo DL, Hobbie SE, Holdaway RJ, Kembel SW, Makita N, Onipchenko VG, Picon-Cochard C, Reich PB, de la Riva EG, Smith SW, Soudzilovskaia NA, Tjoelker MG, Wardle DA, and Roumet C. 2017. Climate, soil and plant functional types as drivers of global fine-root trait variation. Journal of Ecology 105:1182-1196.

Fuhrman JA. 2009. Microbial community structure and its functional implications. Nature 459:193-199. 10.1038/nature08058

Garland JL, and Mills AL. 1991. Classification and Characterization of Heterotrophic Microbial Communities on the Basis of Patterns of Community-Level Sole-Carbon-Source Utilization. Applied and Environmental Microbiology 57:2351-2359.

Grace JB, and Keeley JE. 2006. A structural equation model analysis of postfire plant diversity in California shrublands. Ecological Applications 16:503-514. Doi 10.1890/10510761(2006)016[0503:Asemao]2.0.Co;2

Griffiths RI, Thomson BC, James P, Bell T, Bailey M, and Whiteley AS. 2011. The bacterial biogeography of British soils. Environmental Microbiology 13:1642-1654. 10.1111/j.1462-2920.2011.02480.x

Grigulis K, Lavorel S, Krainer U, Legay N, Baxendale C, Dumont M, Kastl E, Arnoldi C, Bardgett RD, Poly F, Pommier T, Schloter M, Tappeiner U, Bahn M, and Clement JC. 2013. Relative contributions of plant traits and soil microbial properties to mountain grassland ecosystem services. Journal of Ecology 101:47-57. 10.1111/1365-2745.12014

Han M, Sun L, Gan D, Fu L, and Zhu B. 2020. Root functional traits are key determinants of the rhizosphere effect on soil organic matter decomposition across 14 temperate hardwood species. Soil Biology and Biochemistry 151:108019. https://doi.org/10.1016/j.soilbio.2020.108019

Helton JC, and Davis FJ. 2003. Latin hypercube sampling and the propagation of uncertainty in analyses of complex systems. Reliability Engineering \& System Safety 81:23-69. https://doi.org/10.1016/S0951-8320(03)00058-9

Henneron L, Cros C, Picon-Cochard C, Rahimian V, and Fontaine S. 2020. Plant economic strategies of grassland species control soil carbon dynamics through rhizodeposition. Journal of Ecology 108:528-545. https://doi.org/10.1111/1365-2745.13276

Jones DL, Cooledge EC, Hoyle FC, Griffiths RI, and Murphy DV. 2019. pH and exchangeable aluminum are major regulators of microbial energy flow and carbon use efficiency in soil microbial communities. Soil Biology and Biochemistry 138:107584. https://doi.org/10.1016/j.soilbio.2019.107584

Jones DL, Nguyen C, and Finlay RD. 2009. Carbon flow in the rhizosphere: carbon trading at the soil-root interface. Plant and Soil 321:5-33. 
458

459

460

461

462

463

464

465

466

467

468

469

470

471

472

473

474

475

476

477

478

479

480

481

482

483

484

485

486

487

488

489

490

491

492

493

494

495

496

497

498

499

500

501

502

503

504

505

506

507

Klimešová J, Martínková J, and Ottaviani G. 2018. Belowground plant functional ecology: Towards an integrated perspective. Functional Ecology 32:2115-2126. https://doi.org/10.1111/1365-2435.13145

Kuzyakov Y, Friedel JK, and Stahr K. 2000. Review of mechanisms and quantification of priming effects. Soil Biology \& Biochemistry 32:1485-1498.

Ladau J, Shi Y, Jing X, He J-S, Chen L, Lin X, Fierer N, Gilbert JA, Pollard KS, and Chu H. 2018. Climate change will lead to pronounced shifts in the diversity of soil microbial communities. bioRxiv:180174. 10.1101/180174

Lamb EG, Kennedy N, Siciliano SDJP, and Soil. 2011. Effects of plant species richness and evenness on soil microbial community diversity and function. 338:483-495. 10.1007/s11104-010-0560-6

Latz E, Eisenhauer N, Scheu S, and Jousset A. 2015. Plant identity drives the expression of biocontrol factors in a rhizosphere bacterium across a plant diversity gradient. Functional Ecology 29:1225-1234. 10.1111/1365-2435.12417

Laughlin DC. 2011. Nitrification is linked to dominant leaf traits rather than functional diversity. Journal of Ecology 99:1091-1099. 10.1111/j.1365-2745.2011.01856.x

Lear G, Bellamy J, Case BS, Lee JE, and Buckley HL. 2014. Fine-scale spatial patterns in bacterial community composition and function within freshwater ponds. Isme Journal 8:1715-1726. 10.1038/ismej.2014.21

Legendre P, and Fortin MJ. 1989. Spatial pattern and ecological analysis. Vegetatio 80:107138. $10.1007 /$ bf00048036

Liu J, Sui Y, Yu Z, Shi Y, Chu H, Jin J, Liu X, and Wang G. 2014. High throughput sequencing analysis of biogeographical distribution of bacterial communities in the black soils of northeast China. Soil Biology and Biochemistry 70:113-122. https://doi.org/10.1016/j.soilbio.2013.12.014

Lladó S, López-Mondéjar R, and Baldrian P. 2017. Forest Soil Bacteria: Diversity, Involvement in Ecosystem Processes, and Response to Global Change. Microbiology and Molecular Biology Reviews 81:e00063-00016. 10.1128/MMBR.00063-16

López-Angulo J, de la Cruz M, Chacón-Labella J, Illuminati A, Matesanz S, Pescador DS, Pías B, Sánchez AM, and Escudero A. 2020. The role of root community attributes in predicting soil fungal and bacterial community patterns. New Phytologist 228:1070-1082. https://doi.org/10.1111/nph.16754

Martiny JB, Bohannan BJ, Brown JH, Colwell RK, Fuhrman JA, Green JL, Hornerdevine MC, Kane M, Krumins JA, and Kuske CR. 2006. Microbial biogeography: putting microorganisms on the map. Nature Reviews Microbiology 4:102-112.

Martiny JBH, Eisen JA, Penn K, Allison SD, and Horner-Devine MC. 2011. Drivers of bacterial beta-diversity depend on spatial scale. Proceedings of the National Academy of Sciences of the United States of America 108:7850-7854. 10.1073/pnas.1016308108

Materechera SA, Dexter AR, and Alston AM. 1991. Penetration of Very Strong Soils by Seedling Roots of Different Plant-Species. Plant and Soil 135:31-41. Doi 10.1007/Bf00014776

McCormack ML, Adams TS, Smithwick EAH, and Eissenstat DM. 2012. Predicting fine root lifespan from plant functional traits in temperate trees. New Phytologist 195:823-831. 10.1111/j.1469-8137.2012.04198.x

McKay MD, Beckman RJ, and Conover WJ. 1979. Comparison of Three Methods for Selecting Values of Input Variables in the Analysis of Output from a Computer Code. Technometrics 21:239-245. 10.1080/00401706.1979.10489755

Mulder VL, de Bruin S, and Schaepman ME. 2013. Representing major soil variability at regional scale by constrained Latin Hypercube Sampling of remote sensing data. International Journal of Applied Earth Observation and Geoinformation 21:301-310. https://doi.org/10.1016/j.jag.2012.07.004 
508

509

510

511

512

513

514

515

516

517

518

519

520

521

522

523

524

525

526

527

528

529

530

531

532

533

534

535

536

537

538

539

540

541

542

543

544

545

546

547

548

549

550

551

552

553

554

555

556

557

558

Pausch J, and Kuzyakov Y. 2011. Photoassimilate allocation and dynamics of hotspots in roots visualized by $14 \mathrm{C}$ phosphor imaging. 174:12-19. doi:10.1002/jpln.200900271

Pervaiz ZH, Contreras J, Hupp BM, Lindenberger JH, Chen D, Zhang Q, Wang C, Twigg P, and Saleem M. 2020. Root microbiome changes with root branching order and root chemistry in peach rhizosphere soil. Rhizosphere 16:100249. https://doi.org/10.1016/j.rhisph.2020.100249

Phillips RP, and Fahey TJ. 2006. Tree Species and Mycorrhizal Associations Influence the Magnitude of Rhizosphere Effects. Ecology Letters 87:1302-1313.

Prober SM, Leff JW, Bates ST, Borer ET, Firn J, Harpole WS, Lind EM, Seabloom EW, Adler PB, and Bakker JD. 2015. Plant diversity predicts beta but not alpha diversity of soil microbes across grasslands worldwide. Ecology Letters 18:85-95.

Ranjard L, Dequiedt S, Prevost-Boure NC, Thioulouse J, Saby NPA, Lelievre M, Maron PA, Morin FER, Bispo A, Jolivet C, Arrouays D, and Lemanceau P. 2013. Turnover of soil bacterial diversity driven by wide-scale environmental heterogeneity. Nature Communications 4. ARTN 143410.1038/ncomms2431

Rousk J, Brookes PC, and Bååth E. 2010. The microbial PLFA composition as affected by pH in an arable soil. Soil Biology and Biochemistry 42:516-520. https://doi.org/10.1016/j.soilbio.2009.11.026

Saleem M, Pervaiz ZH, Contreras J, Lindenberger JH, Hupp BM, Chen D, Zhang Q, Wang C, lqbal J, and Twigg P. 2020. Cover crop diversity improves multiple soil properties via altering root architectural traits. Rhizosphere 16:100248. https://doi.org/10.1016/j.rhisph.2020.100248

See CR, Luke McCormack M, Hobbie SE, Flores-Moreno H, Silver WL, and Kennedy PG. 2019. Global patterns in fine root decomposition: climate, chemistry, mycorrhizal association and woodiness. Ecology Letters 22:946-953. 10.1111/ele.13248

Severin I, Ostman O, and Lindstrom ES. 2013. Variable Effects of Dispersal on Productivity of Bacterial Communities Due to Changes in Functional Trait Composition. Plos One 8. ARTN e8082510.1371/journal.pone.0080825

Shen CC, Xiong JB, Zhang HY, Feng YZ, Lin XG, Li XY, Liang WJ, and Chu HY. 2013. Soil pH drives the spatial distribution of bacterial communities along elevation on Changbai Mountain. Soil Biology \& Biochemistry 57:204-211. 10.1016/j.soilbio.2012.07.013

Stursova M, Barta J, Santruckova H, and Baldrian P. 2016. Small-scale spatial heterogeneity of ecosystem properties, microbial community composition and microbial activities in a temperate mountain forest soil. Fems Microbiology Ecology 92. ARTN fiw18510.1093/femsec/fiw185

Sugden AM. 2018. A global map of soil bacteria. Science 359:285. 10.1126/science.359.6373.285-n

Tian J, Fan MS, Guo JH, Marschner P, Li XL, and Kuzyakov Y. 2012. Effects of land use intensity on dissolved organic carbon properties and microbial community structure. European Journal of Soil Biology 52:67-72. 10.1016/j.ejsobi.2012.07.002

Tian J, He NP, Hale L, Niu SL, Yu GR, Liu Y, Blagodatskaya E, Kuzyakov Y, Gao Q, and Zhou JZ. 2018. Soil organic matter availability and climate drive latitudinal patterns in bacterial diversity from tropical to cold temperate forests. Functional Ecology 32:61-70. 10.1111/1365-2435.12952

Tian J, McCormack L, Wang JY, Guo DL, Wang QF, Zhang XY, Yu GR, Blagodatskaya E, and Kuzyakov Y. 2015. Linkages between the soil organic matter fractions and the microbial metabolic functional diversity within a broad-leaved Korean pine forest. European Journal of Soil Biology 66:57-64. https://doi.org/10.1016/j.ejsobi.2014.12.001

Tripathi BM, Stegen JC, Kim M, Dong K, Adams JM, and Lee YK. 2018. Soil pH mediates the balance between stochastic and deterministic assembly of bacteria. The ISME Journal 12:1072-1083. 10.1038/s41396-018-0082-4

Peer) reviewing PDF | (2020:09:52658:2:0:NEW 12 Jan 2021) 
559 Waisel Y, Eshel A, Beeckman T, and Kafkafi U. 2002. Plant Roots: The Hidden Half. Crc Press.

560

561

562

563

564

565

566

567

568

Wang JT, Zheng YM, Hu HW, Li J, Zhang LM, Chen BD, Chen WP, and He JZ. 2016. Coupling of soil prokaryotic diversity and plant diversity across latitudinal forest ecosystems. Scientific Reports 6.

Zhang JH, Han SJ, and Yu GR. 2006. Seasonal variation in carbon dioxide exchange over a 200-year-old Chinese broad-leaved Korean pine mixed forest. Agricultural and Forest Meteorology 137:150-165. 10.1016/j.agrformet.2006.02.004

Zhao QO, Zeng DH, and Fan ZP. 2010. Nitrogen and phosphorus transformations in the rhizospheres of three tree species in a nutrient-poor sandy soil. Applied Soil Ecology

569 46:341-346. 10.1016/j.apsoil.2010.10.007 


\section{Figure 1}

Relative abundances of the dominant bacterial (A) phylum and (B) class in the broadleaved Korean pine forest.

The relative abundances are based on the proportional frequencies of the classified DNA sequences. 
A

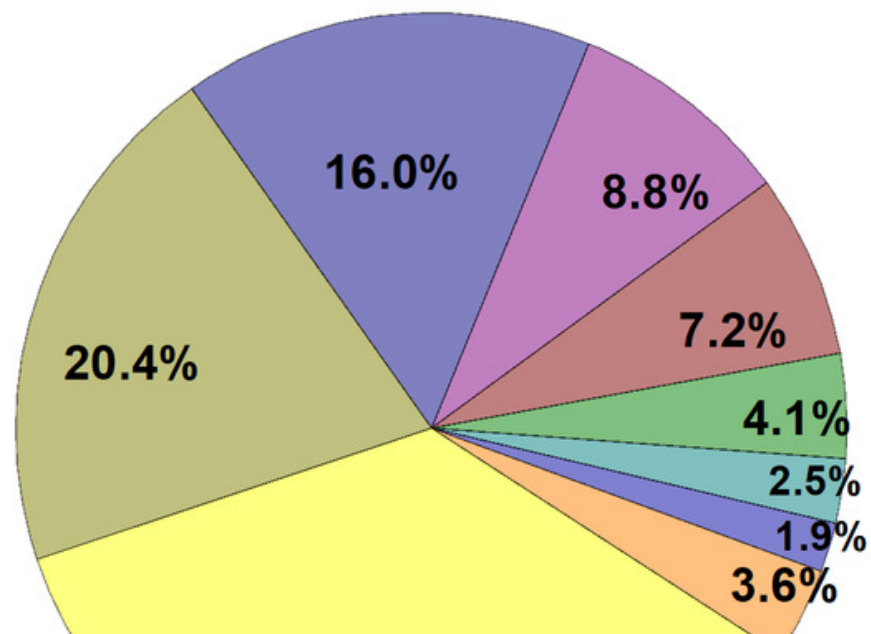

$35.2 \%$

B

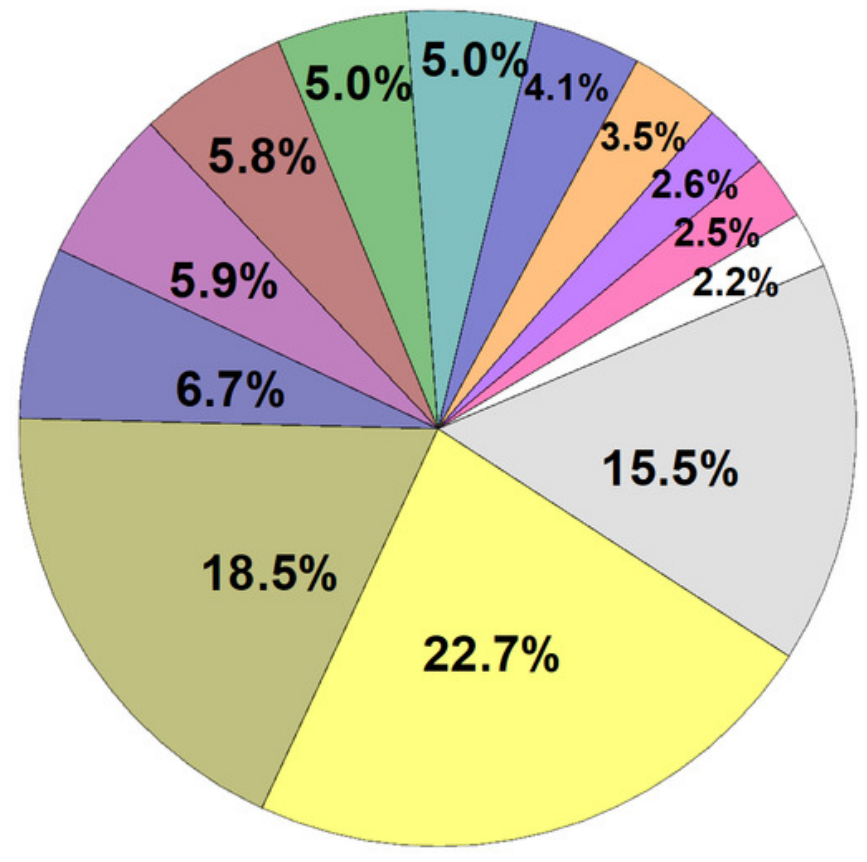

Proteobacteria Acidobacteria Actinobacteria Chloroflexi Verrucomicrobia Bacteroidetes Nitrospirae Gemmatimonadetes Others

\begin{tabular}{|l|l|}
\hline & Alphaproteobacteria \\
\hline & Acidobacteria \\
Spartobacteria \\
Thermoleophilia \\
Actinobacteria \\
Deltaproteobacteria \\
\hline Betaproteobacteria \\
Ktedonobacteria \\
\hline Sphingobacteriia \\
\hline Nitrospira \\
\hline$\square$ Gammaproteobacteria \\
\hline$\square$ JG37-AG-4 \\
\hline$\square$ Others
\end{tabular}




\section{Figure 2}

Correlations of bacterial groups and metabolic functions.

${ }^{*} p \leq 0.05 ;{ }^{* *} p \leq 0.01$. The blue-red bar on the right shows the negative-positive correlations.

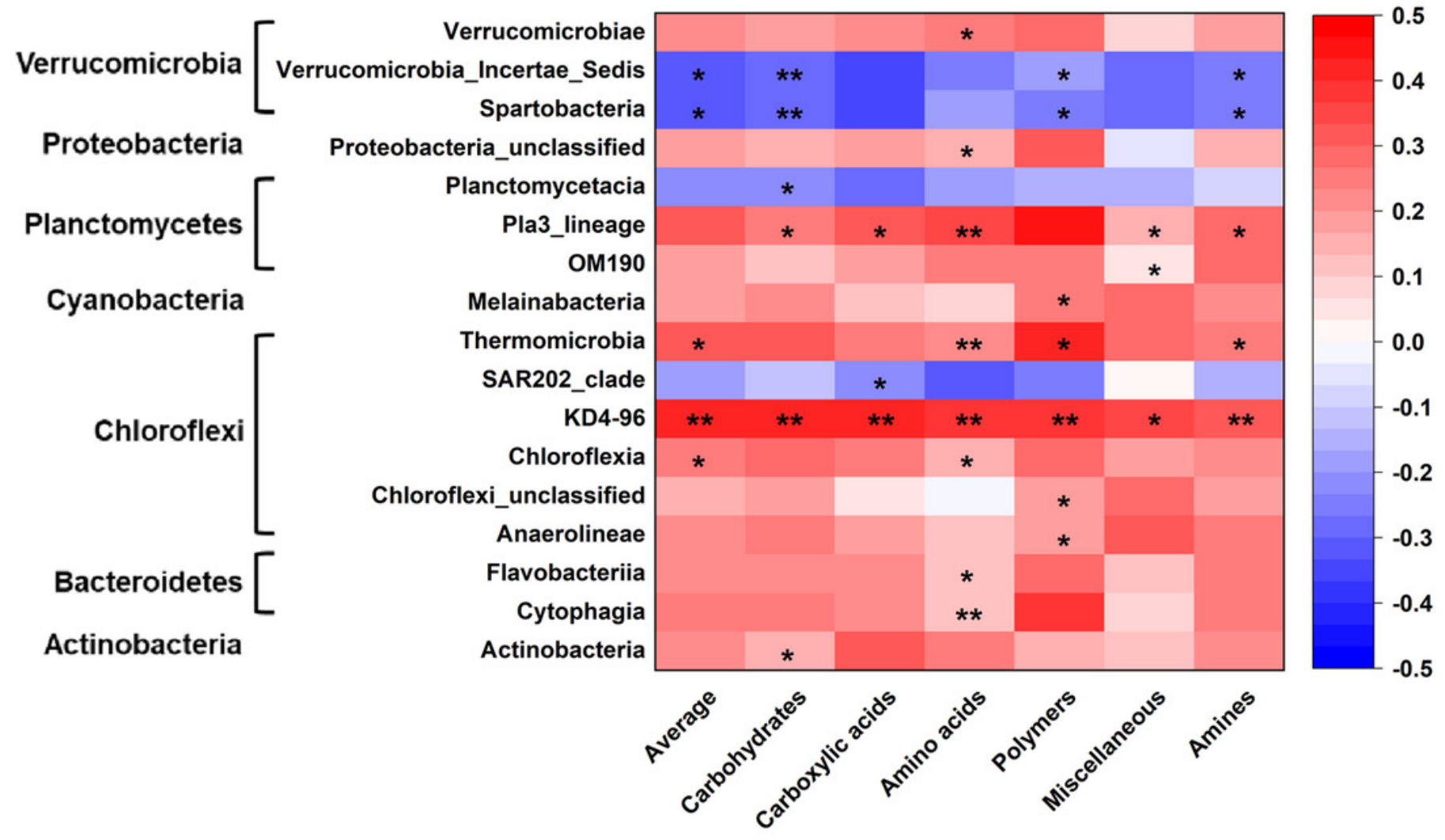




\section{Figure 3}

Relationship between Bray-Curtis community dissimilarity and geographic distance for (A) bacterial community composition and (B) metabolic functions.

Each data point represents the Bray-Curtis dissimilarity score for two samples and the geographic distance between the samples.
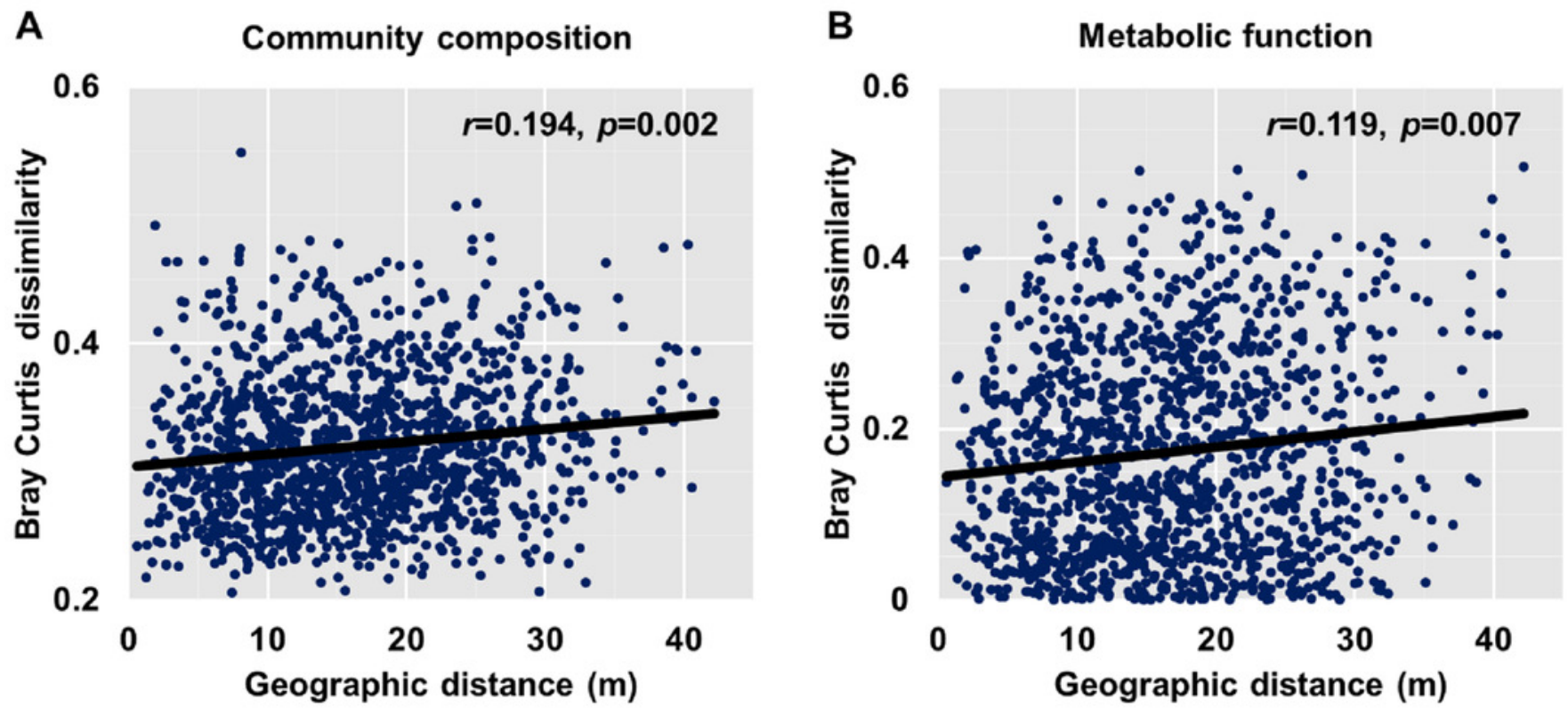
Figure 4

Relationships between dissimilarity and geographic distance for dominant bacterial phyla.

(A) Proteobacteria. (B) Acidobacteria. (C) Actinobacteria. (D) Chloroflexi. (E) Verrucomicobia.

(F) Nitrospirae. (G) Bacteroidetes. (H) Gemmatimonadetes. Each data point represents the

Bray-Curtis dissimilarity score for two samples and the geographic distance between the samples.
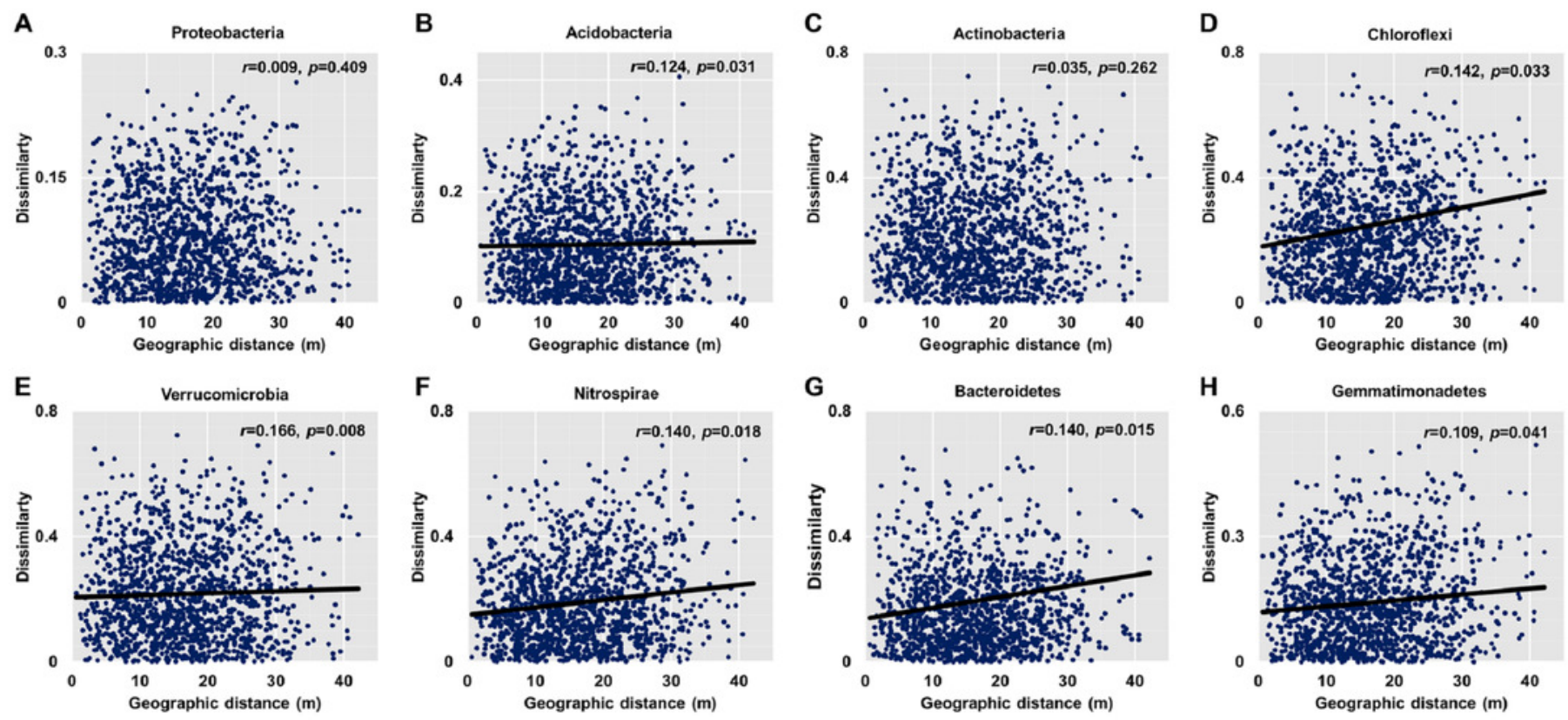
Figure 5

Relationships between dissimilarity and geographic distance for six metabolic functions.

(A) Carbohydrates. (B) Carboxylic acids. (C) Amino acids. (D) Polymers. (E) Miscellaneous. (F) Amines. Each data point represents the Bray-Curtis dissimilarity score for two samples and the geographic distance between the samples.

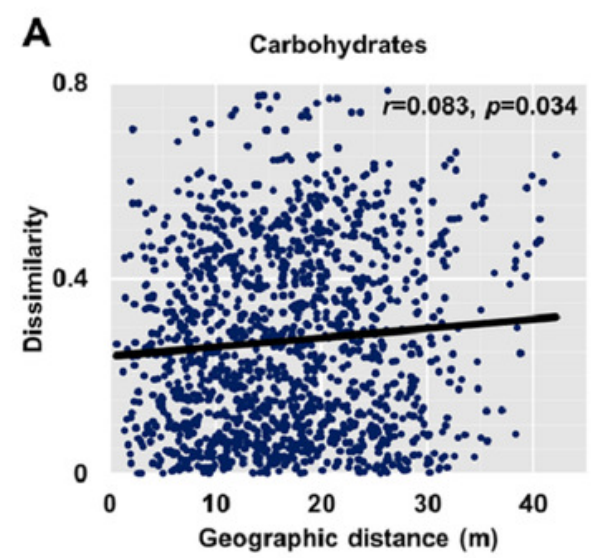

D

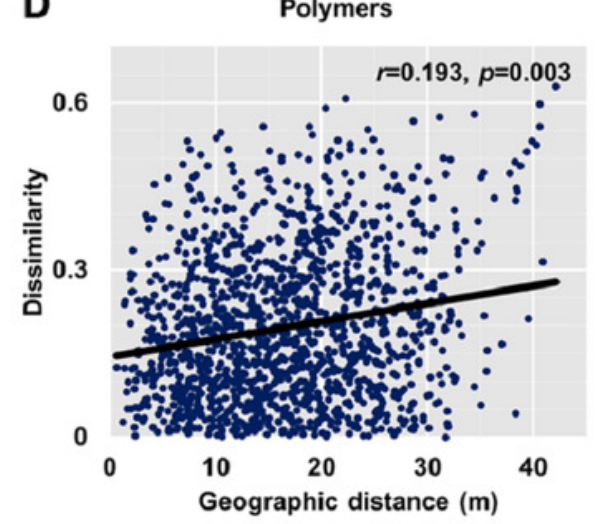

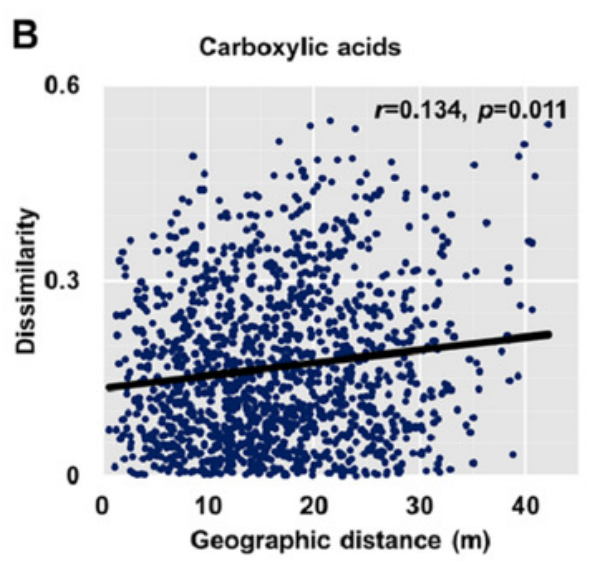

$E$

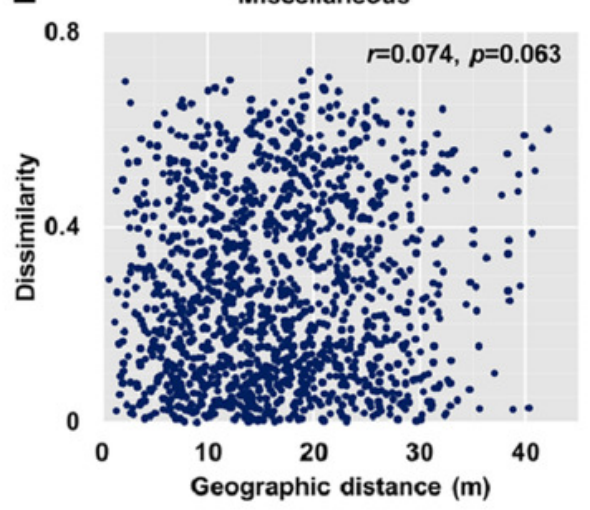

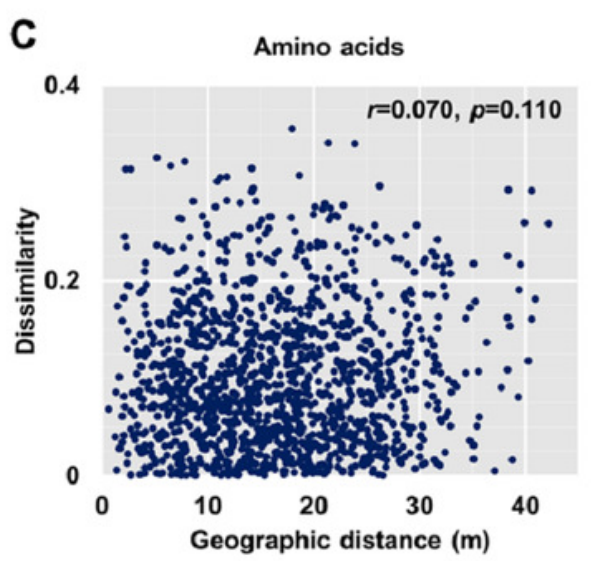

$\mathbf{F}$

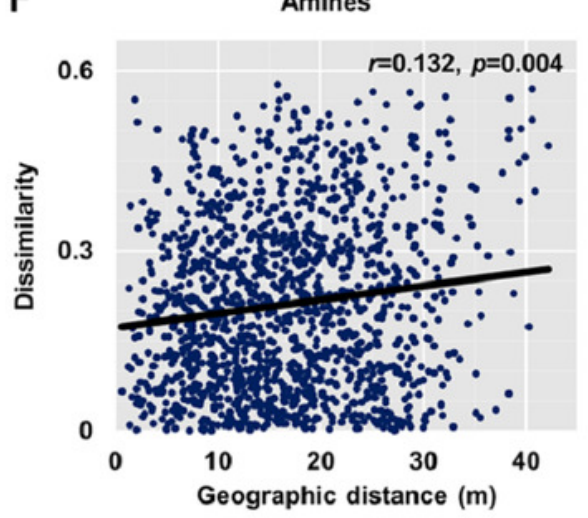




\section{Figure 6}

Multivariate Mantel correlograms showing the significance of spatial autocorrelation in (A) bacterial composition and (B) functions.

Solid black points represent scales with significant $(p<0.05)$ spatial autocorrelation (positive Mantel correlation values) or spatial clustering (negative Mantel correlation values). Open points represent non-significant values. Holm's correction was applied for multiple comparisons. Therefore, 'scale values' on the plots provide the approximate distances on the correlograms, where spatial autocorrelation in bacterial composition or functions between samples becomes non-significant (that is, only communities separated by distances greater than the scale values are likely differ significantly). 


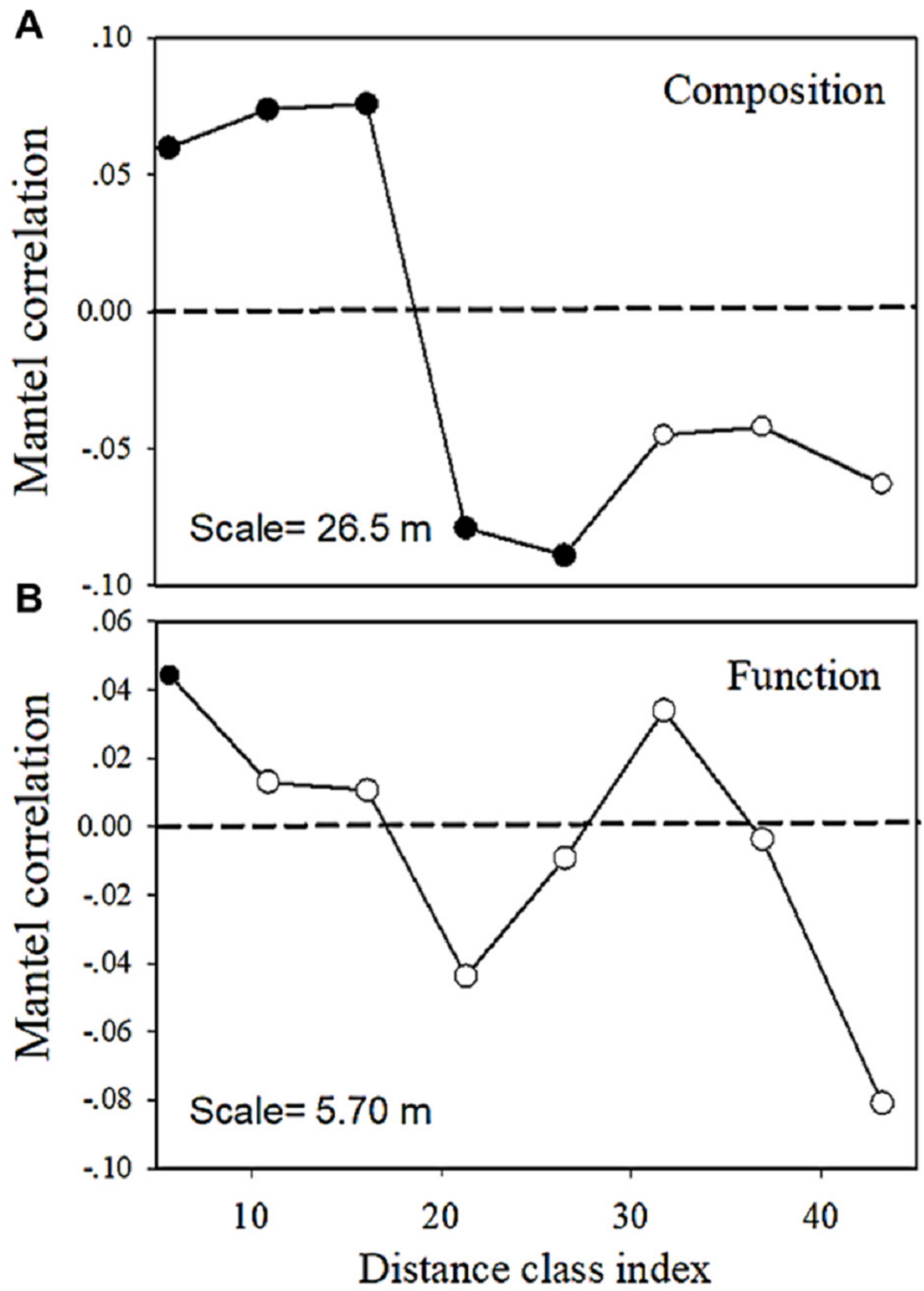




\section{Figure 7}

The heatmap of the Pearson's correlation coefficients of the relative abundances of dominant bacterial groups and metabolic functions with plant and soil properties.

${ }^{*} p \leq 0.05 ; * * \leq 0.01$

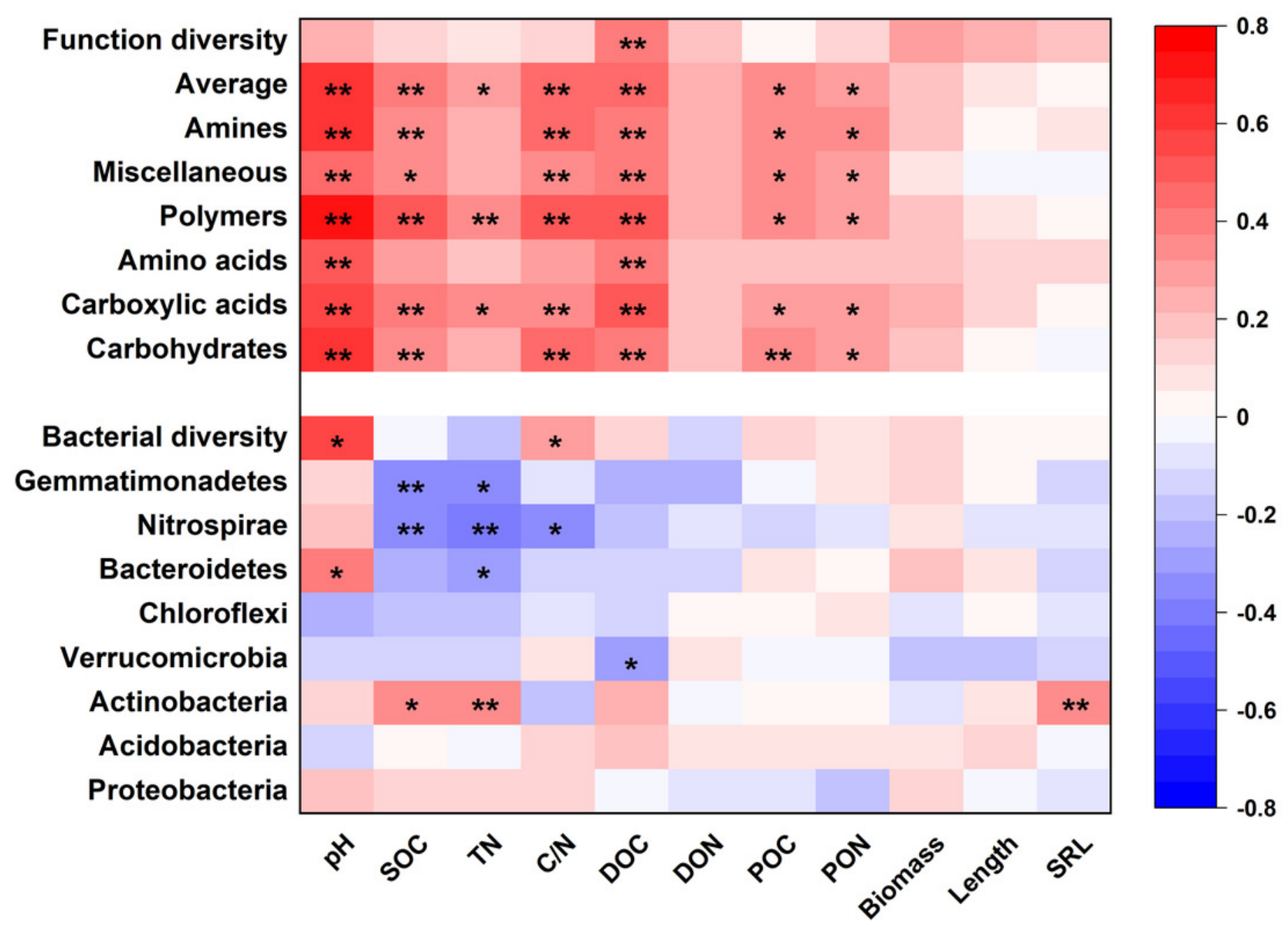




\section{Figure 8}

Direct and indirect effects of soil nutrients and root traits on beta-diversity of bacterial community composition and metabolic functions.

Structural equation models are shown for the (A) bacterial community and (B) metabolic functions. Arrows represent causal relationships. Numbers on arrows are standardized path coefficients. Percentages in circles indicate the variance explained by the model $\left(R^{2}\right)$. Asterisks denote the level of significance: ${ }^{*} p \leq 0.05 ;{ }^{* *} p \leq 0.01 ;{ }^{* * *} p \leq 0.001$. 
A

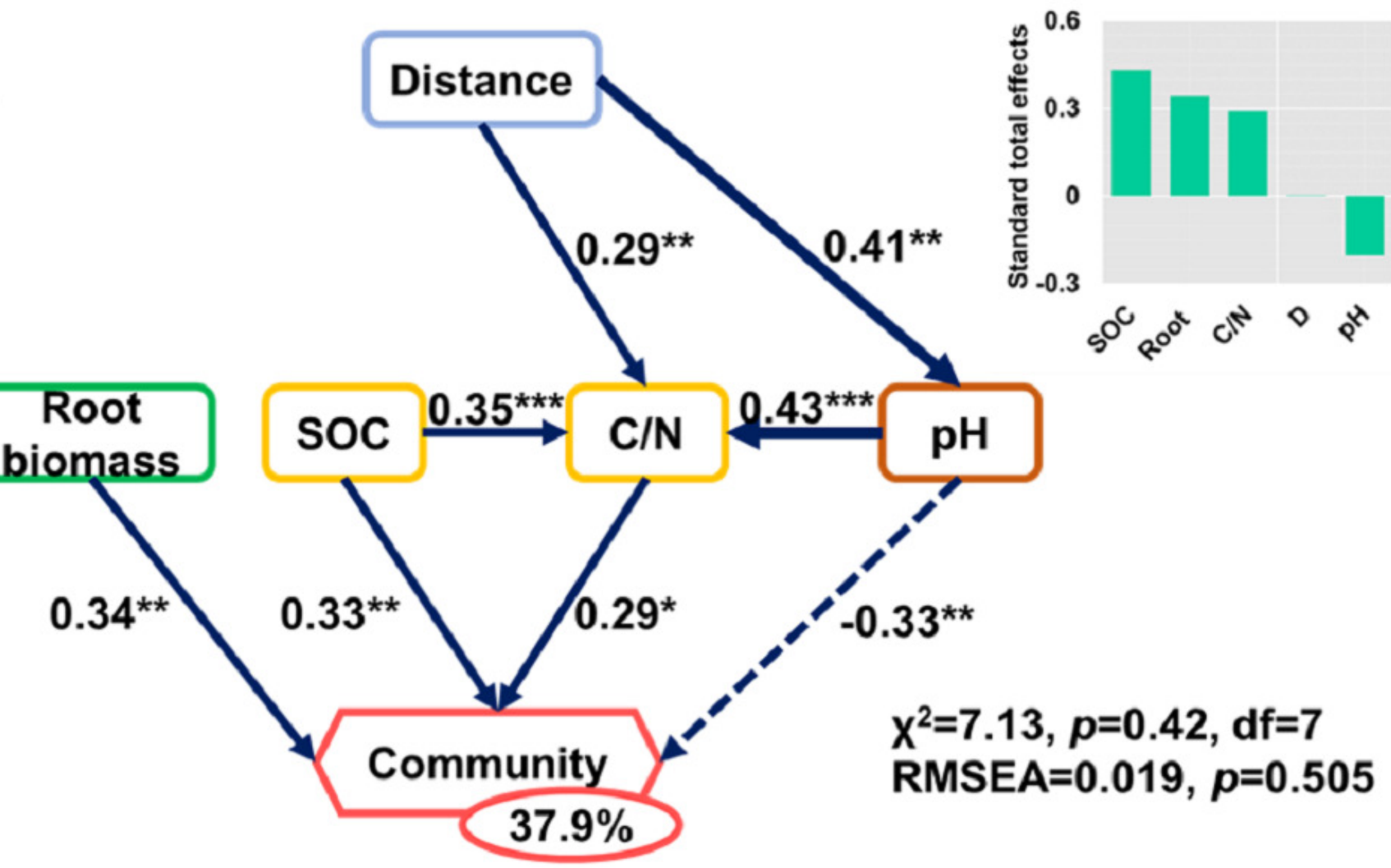

B

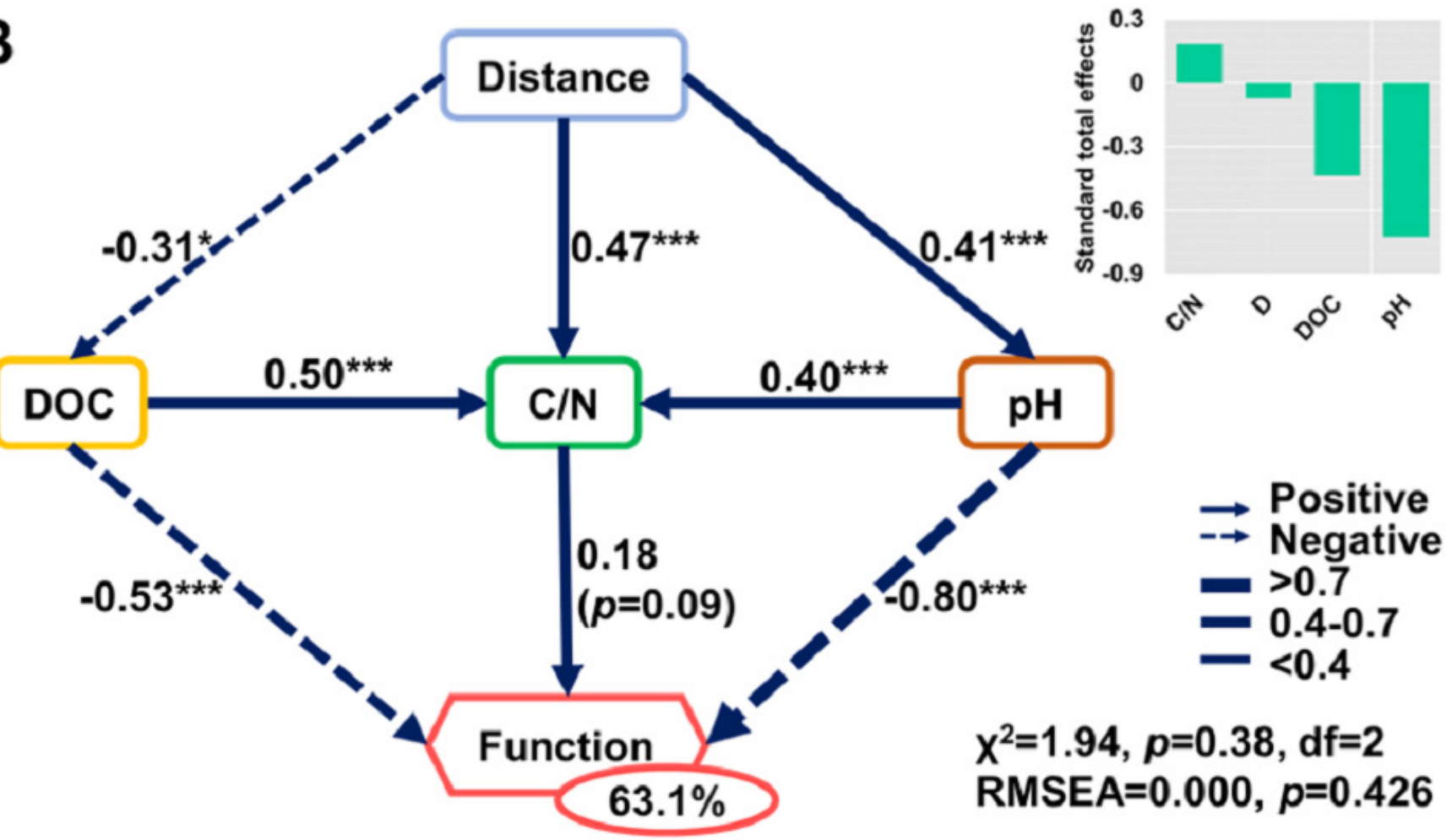

